\title{
Pengaruh Kontrol Diri Terhadap Tingkat Religiusitas Siswa Kelas VIII di SMP Negeri 4 Pare Kediri
}

\author{
Julianne Kamelia Riza \\ mila_faruq@yahoo.com \\ Prodi PAI STIT Al-Urwatul Wutsqo Jombang
}

\begin{abstract}
Self-control is an activity of individual self-control of their behavior where an individual has faith in their God which is called religiosity. The difference in the level of religiosity triggers various problems in society, especially students who are at puberty, and develop in a variety of environments. This research was conducted on grade VIII students at SMP Negeri 4 Pare Kediri, aims to determine the students' self-control and religiosity level, as well as how the influence of self-control on the level of religiosity. This type of research is quantitative research with self-control as the independent variable, and the level of religiosity as the dependent variable. The instrument used in this study was the self-control scale and the level of religiosity given to 72 subjects who were taken by random sampling. Hypothesis testing in this study using linear regression test with SPSS for Windows 16.0. The test results of the SPSS for Windows 16.0 program stated that these students on average had good selfcontrol and a high level of religiosity. Based on the R-square value, there is an influence between the variable $X$ and $Y$ in the weak category of $20 \%$, while $80 \%$ is influenced by other factors that are not studied.
\end{abstract}

Keywords: Self-control, Relegius

\section{Pendahuluan}

Era globalisasi yang sedang terjadi di dunia ini mempunyai dampak positif dan negatif. Dapat kita cermati yang sedang terjadi di Indonesia, maraknya dampak negatif yang menyerang masyarakat kita terutama para pelajar di Indonesia di usia remaja, perkembangan sikap yang cukup rawan pada remaja adalah sikap comformity yaitu kecenderungan untuk menyerah dan mengikuti bagaimana teman sebayanya berbuat. Misalnya dalam hal pendapat, pikiran, nilainilai, gaya hidup, kebiasaan, kegemaran, keinginan, dan lain-lainnya. Bellak dalam Fuhrmann secara khusus membahas pengaruh tekanan media terhadap perkembangan remaja. Menurutnya remaja masa kini dihadapkan pada 
lingkungan dimana segala sesuatu berubah sangat cepat. Mereka dibanjiri oleh informasi yang terlalu banyak dan terlalu cepat untuk diserap dan dimengerti. Semuanya terus bertumpuk hingga mencapai apa yang disebut information overload. Akibatnya timbul perasaan terasing, keputusasaan, absurditas, problem identitas dan masalah-masalah yang berhubungan dengan benturan budaya. ${ }^{1}$

Koentjoro menyatakan bahwa penyalahgunaan Narkoba di Yogyakarta mengalami peningkatan, dan berakibat pada meluasnya perilaku seks bebas remaja. Data hasil penelitian Pusat Studi Wanita (PSW) Universitas Negeri Yogyakarta (UNY) menyatakan bahwa 52,1 \% remaja tidak memperhatikan Virginitas dan 47,9 \% remaja tidak memperhatikan keperjagaan, hal ini mengakibatkan maraknya seks bebas di kalangan remaja. Lebih lanjut Koentjoro menyatakan bahwa perilaku tawuran, seks bebas dan kecanduan narkotika yang dialami remaja merupakan indikasi rendahnya kontrol diri.

Kontrol diri diartikan sebagai kemampuan untuk menyusun, membimbing, mengatur dan mengarahkan bentuk perilaku yang dapat membawa ke arah konsekuensi positif. Kontrol diri merupakan salah satu potensi yang dapat dikembangkan dan digunakan individu selama proses-proses dalam kehidupan, termasuk dalam menghadapi kondisi yang terdapat dalam di lingkungan sekitarnya. Para ahli berpendapat bahwa kontrol diri dapat digunakan sebagai suatu intervensi yang bersifat preventif selain dapat mereduksi efek-efek psikologis yang negatif dari stressor-stressor lingkungan. ${ }^{2}$ Calhoun dan Acocella mendefinisikan kontrol diri (self-control) sebagai pengaturan proses-proses fisik, psikologis, dan perilaku seseorang, dengan kata lain serangkaian proses yang membentuk dirinya sendiri. Goldfried dan Merbaum dalam Lazarus mendefinisikan kontrol diri sebagai suatu kemampuan untuk menyusun, membimbing, mengatur, dan mengarahkan bentuk perilaku yang dapat membawa individu ke arah konsekuensi positif. Kontrol diri juga menggambarkan keputusan

\footnotetext{
${ }^{1}$ Alwi, Said, Perkembangan Religiusitas Remaja (Yogyakarta: Kaukaba Dipantara, 2014), 62-63.

2 M. Nur Ghufron \& Rini Risnawati S, Teori-Teori Psikologi (Jogjakarta: Ar-Ruzz Media, 2014 ), 21.
} 
individu yang melalui pertimbangan kognitif untuk menyatukan perilaku yang telah disusun untuk meningkatkan hasil dan tujuan tertentu yang diinginkan.

Ketika berinteraksi dengan orang lain, seseorang akan berusaha menampilkan perilaku yang dianggap paling tepat bagi dirinya, yaitu periaku yang dapat menyelamatkan interaksinya dari akibat negatif yang disebabkan karena respons yang dilakukannya. Kontrol diri diperlukan guna membantu individu dalam mengatasi kemampuannya yang terbatas dan mengatasi berbagai hal merugikan yang mungkin terjadi yang berasal dari luar. ${ }^{3}$

Berdasarkan teori di atas, peneliti menyimpulkan bahwa kontrol diri adalah kemampuan individu untuk memandu, mengarahkan dan mengatur perilakunya dalam menghadapi stimulus sehingga menghasilkan akibat yang diinginkan dan menghindari akibat yang tidak diinginkan. Kontrol diri juga dapat diartikan sebagai suatu aktivitas pengendalian tingkah laku. Individu memiliki pertimbangan-pertimbangan ketika berperilaku. Semakin tinggi kontrol diri seseorang, maka semakin tinggi pengendalian diri individu terhadap tingkah lakunya. Menurut Said Alwi seiring waktu individu akan mengalami perkembangan dari masa kanak-kanak hingga dewasa sehingga terjadi perubahan fisik, kognitif dan psikososial yang diantaranya dapat mempengaruhi keyakinan individu itu sendiri.

Seorang yang mempunyai keyakinan dalam dirinya mempunyai tingkat fanatik yang berbeda-beda setiap orangnya. Hubungan dirinya dengan Tuhannya meruapkan suatu hal yang dapat kita lihat dalam diri seseorang untuk mengukur tingkat keyakinannya. Hubungan diri dengan Tuhan dalam istilah dapat disebut religiusitas. Melihat fenomena yang ada di masyarakat kita terutama para pelajar yang ada di Indonesia, terdapat bayak sekali perbedaan tingkat religiusitas. Bagi mereka yang memiliki tingkat religiusitas tinggi maka akan membuktikan perbuatannya dengan terpuji, sebaliknya mereka yang memiliki tingkat religiusitas rendah maka juga akan mempengaruhi dampak negatif pada dirinya sendiri. Ini membuktikan religiusitas seseorang dapat dikatakan sangatlah penting

${ }^{3}$ Ibid., 22-23. 
apalagi pada penerus bangsa ini. Banyak sekolah-sekolah yang mengadakan kegiatan-kegiatan religi yang dipandang sangatlah penting sebagai faktor positif untuk merubah kepribadian siswa ke arah yang lebih baik.

Dikatakan Gazalba (1987) religiusitas berasal dari kata religi dalam bahasa Latin "religio" yang akar katanya adalah religure yang berarti mengikat. Dengan demikian, mengandung makna bahwa religi atau agama pada umunya memiliki aturan-aturan dan kewajiban-kewajiban yang harus dipatuhi dan dilksanakan oleh pemeluknya. Kesemuanya itu berfungsi mengikat seseorang atau sekelompok orang dalam hubungannya dengan Tuhan, sesama manusia dan alam sekitarnya.

Anshori (1980) membedakan antara istilah religi atau agama dengan religiusitas. Jika agama menunjuk pada aspek-aspek formal yang berkatian dengan aturan dan kewajiban, maka religiusitas menunjuk pada aspek religi yang telah dihayati oleh seseorang dalam hati. Pendapat tersebut senada dengan Dister dalam Subandi (1988) yang mengartikan religiusitas sebagai keberagaman karena adanya internalisasi agama ke dalam diri seseorang. Monks dkk. (1989) mengartikan keberagaman sebagai keterdekatan yang lebih tinggi dari manusia kepada Yang Maha Kuasa yang memberikan perasaan aman. ${ }^{4}$

Berdasar dari beberapa teori di atas peneliti menyimpulkan bahwa religiusitas merupakan suatu keyakinan dan penghayatan akan ajaran agama yang mengarahkan perilaku seseorang dan pandangan hidupnya dengan ajaran yang dianutnya. Seseorang yang kurang membekali dirinya dengan arahan dan bimbingan keagamaan dalam kehidupannya, maka kondisi seperti ini yang akan menjadi pemicu berkembangnya perilaku seseorang yang semakin meningkat dan akan berdampak pada setiap perbuatannya, serta lebih memudahkan seseorang melakukan perbuatan yang dilarang agama.

Kegiatan keagamaan di instansi pendidikan merupakan suatu hal yang dapat membantu mengarahkan seseorang ke arah yang lebih baik dalam menganut keyakinannya. Salah satunya kegiatan shalat dhuha yang ada di salah satu Sekolah Menengah Pertama di Pare yaitu SMP Negeri 4 Pare khususnya kelas VIII. SMP

${ }^{4}$ Ibid.,167-168. 
Negeri 4 Pare berlokasi di Jalan Merbabu Kecamatan Pare Kabupaten Kediri, terletak di sebelah Pasar Pamenang Pare yang penuh dengan keramaian. Berdasar pengalaman pada seorang siswa kelas VIII yang rutin melaksanakan kegiatan keagamaan di sana, seiring waktu dapat mengubah perilakunya dalam mengontrol diri sehingga di masyarakat dapat menyesuaikan tindak tanduk sebagaimana yang diterapkan di masyarakat tersebut terutama dalam situasi religius.

Sekolah Menengah Pertama (SMP), dimana siswa kelas VIII berusia \pm 13-15 tahun. Dra. Susilowindradini, untuk menghindari salah paham, berpatokan pada literatur Amerika dalam menentukan masa pubertas (11/12 - 15/16 tahun). Perilaku sebagai sebagian ciri pubertas ini ditunjukkan dalam sikap, perasaan, keinginan dan perbuatan-perbuatan. Sikap pubertas yang paling menonjol antara lain adalah sikap tidak tenang dan tidak menentu.

Melihat realita yang terjadi pada siswa kelas VIII di sekolah tersebut dengan rentang usia pada masa-masa pubertas ditambah dengan kondsi lingkungan yang rama dan bebas, sekolah tersebut mengadakan kegiatan keagamaan di sela-sela aktifitas kegiatan belajar mengajar.

\section{Kajian Teori.}

\section{Kontrol Diri}

Kontrol diri berkaitan dengan bagaimana dengan bagaimana individu mengendalikan emosi serta dorongan-dorongan dari dalam dirinya. ${ }^{5}$ Hurlock (1973) menyebutkan tiga kriteria emosi. Di bawah ini adalah tiga kriteria emosi tersebut. ${ }^{6}$ Dapat melakukan kontrol diri yang bisa diterima secara sosial, dapat memahami seberapa banyak kontrol yang dibutuhkan untuk memuaskan kebutuhannya dan sesuai dengan harapan masyarakat dan Dapat menilai situasi secara kritis sebelum meresponsnya dan memutuskan cara beraksi terhadap situasi tersebut.

\footnotetext{
${ }^{5}$ M. Nur Ghufron \& Rini Risnawati S, 23.

${ }^{6}$ Ibid.,24.
} 
Menurut Averil dalam Adeonalia mengatakan aspek-aspek yang terdapat dalam kontrol diri antara lain:

a. Kemampuan mengontrol perilaku

Dalam hal ini perilaku sangat penting peranannya sehingga apabila perilaku seeorang tidak terkontrol maka dapat terjadi perilaku yang menyimpang, meskipun kemampuan mengontrol perilaku pada tiap-tiap individu berbeda.

b. Kemampuan mengontrol stimulus

Kemampuan mengontrol stimulus juga menjadi salah satu aspek dari kontrol diri karena dalam kehidupan seseorang terdapat berbagai macam stimulus yang diterima. Dari berbagai macam stimulus yang masuk tersebut individu harus mempunyai kemampuan untuk mengontrol stimulus-stimulus tersebut, yaitu dengan memilah stimulus yang mana yang harus diterima dan stimulus yang harus ditolak.

c. Kemampuan mengantisipasi peristiwa

Individu dalam menghadapi suatu masalah atau suatu peristiwa harus memiliki kemampuan untuk mengantisipasi asalah tersebut agar tidak menjadi masalah yang semakin besar dan rumit.

d. Kemampuan menafsirkan peristiwa

Individu juga harus mempunyai kemampuan untuk menafsirkan peristiwa, artinya individu harus dapat mengartikan semua peristiwa yang terjadi dalam kehidupannya, sehingga individu dapat dengan mudah untuk menjalani peristiwa tersebut dan dapat memikirkan langkah-langkah apa yang akan dilakukan selanjutnya.

e. Kemampuan mengambil keputusan

Dalam setiap peristiwa pasti ada sesuatu yang harus diputuskan. Setiap individu harus mempunyai kemampuan untuk mengambil suatu keputusan yang baik, dimana keputusan yang diambil tersebut baik untuk diri individu sendiri maupun bagi orang lain yang ada di sekitarnya, juga tidak merugikan diri sendiri maupun orang lain. 
Kesimpulan dari aspek-aspek yang disebutkan di atas adalah apabila individu mempunyai kemampuan-kemampuan yang terdapat dalam aspekaspek tersebut maka individu dapat mengontrol dirinya dengan baik sebaik mungkin, dan individu dapat terhindar dari masalah yang tidak diinginkan. ${ }^{7}$

\section{Religiusitas}

Religiusitas (religiosity) bermakna religious feeling or sentiment "perasaan agama" (The World Book Dictionary, 1980). Akar kata religiusitas adalah religion sering juga disebut religi )latin: religure) yang berarti ikatan atau pengikatan diri (Driyarkara, 1978). Religion kemudian diartikan sebagai hbungan yang mengikat antara diri manusia, yaitu Tuhan. Dalam Religi umumnya terdapat aturan-aturan dan kewajiban yang harus dilaksanakan, yang berfungsi untuk mengikat dan mengutuhkan diri seseorang atau sekelompok orang dalam hubungannya dengan Tuhan, sesama dan alam sekitar. ${ }^{8}$

Jalaluddin (2001) mengemukakan bahwa religiusitas merupakan sikap keagamaan, yaitu suatu keadaan yang ada dalam diri seseorang yang mendorongnya untuk bertingkah laku sesuai kadar ketaatannya terhadap agama. Pendapat tersebut lebih menekankan pada ketaatan seseorang terhadap ajaran agamanya, yang diwujudkan dalam tingkah laku. ${ }^{9}$

\section{Dimensi - Dimensi Religiusitas}

Glock dan Stark dalam Ancok dan Suroso membagi aspek keberagaman yaitu:

a. Dimensi keyakinan (the ideological dimension), tingkatan sejauh mana seseorang menerima dan mengakui hal-hal yang dogmatik dalam agamanya. Misalnya keyakinan adanya sifat-sifat Tuhan, adanya malaikat, surga, para Nabi dan lain sebagainya.

b. Dimensi peribadatan atau praktek agama (the ritualistic dimension) yaitu tingkatan sejauh mana seseorang menunaika kewajiban-kewajiban ritual

\footnotetext{
${ }^{7}$ D Nadifa Andriani, "Kajian Teori Kontrol Diri” (Jurnal UIN Malang, 2014), (online) http://etheses.uinmalang.ac.id, diakses pada tanggal 08 agustus 2017.

${ }^{8}$ Said Alwi, Perkembangan Religiusitas Remaja, 1.

${ }^{9}$ Ibid., 3.
} 
dalam agamanya. Misalnya menunaikan shalat, zakat, puasa, haji, dan sebagainya.

c. Dimensi feeling atau penghayatan (the experiencal) yaitu perasaaan keagamaan yang pernah dialami dan dirasakan seperti merasa dekat dengan Tuhan, tentram saat berdo'a, tersentuh mendengar ayat-ayat kitab suci, merasa takut berbuat dosa, merasa senang do'anya dikabulkan dan sebagainya.

d. Dimensi pengetahuan agama (the intellectual dimension) yaitu seberapa jauh seseorang mengetahui dan memahami ajaran-ajaran agamanya terutama yang ada dalam kitab suci, hadits, pengetahuan tentang fiqh dan sebagainya.

e. Dimensi effect atau pengamalan (the consequential dimension) yaitu sejauh mana implikasi ajaran agama mempengaruhi perilaku seseorang dalam kehidupan sosial. Dimensi ini memiliki arti sejauh mana perilaku seseorang dalam kehidupan sehari-hari didorong oleh ajaran agama. Kenyataannya dimensi ini tidak selalu lengkap ada pada seseorang dalam kehidupan seharihari didorong oleh ajaran agama. Kenyataannya dimensi ini tidak selalu lengkap ada pada seseorang dikarenakan sikap, ucapan dan tindakan seseorang tidak selalu atas dorongan ajaran agama. Misalnya mendermakan harta untuk aktivitas keagamaan dan sosial, menjenguk orang sakit, mempererat silaturahmi, berperilaku jujur dan adil, tidak korupsi dan sebagainya. ${ }^{10}$

\section{Metode Penelitian.}

Jenis penelitian yang digunakan oleh peneliti adalah penelitian kuantitatif. Dalam penelitian ini adalah penelitian korelasional yaitu penelitian yang dimaksud untuk mengetahui ada tidaknya pengaruh antara dua variabel. Adapun paradigma penelitianya adalah untuk mencari atau mengetahui pengaruh antara kontrol diri dengan religiusitas siswa kelas VIII di SMP Negeri 4 Pare Kediri.

\footnotetext{
${ }^{10}$ Ibid., 4-5.
} 
Dalam hal ini ada dua variabel, yaitu: Variabel Independent (Variabel Bebas), yaitu yang menjadikan sebab atau mempengaruhi timbulnya atau berubahnya variabel dependent. Dalam hal ini variabel dependentnya adalah kontrol diri. Variabel Dependent (Variabel Terikat), yaitu variabel yang dipengaruhi atau menjadi akibat karena ada variabel independent. ${ }^{11}$

Dalam penelitian ini yang menjadi populasi adalah siswa kelas VIII SMP Negeri 4 Pare Kediri baik dari jenis kelamin laki-laki maupun perempuan yang terdiri dari 10 kelas dari kelas VIII A s.d VIII J dengan jumlah keseluruhan 358 siswa. Sebagaimana dikatakan oleh Suharsimi Arikunto apabila subjeknya kurang dari 100, maka lebih baik diambil semuanya, sehingga penelitiannya merupakan penelitian populasi. Selanjutnya jika jumlah subjeknya besar dapat diambil 10\%$15 \%$, atau $20 \%-25 \%$, atau lebih." 12

Hal ini yang menjadi subjek penelitian adalah seluruh siswa kelas VIII SMP Negeri 4 Pare Kediri dengan jumlah keseluruhan adalah 358 siswa. Dan data tersebut jumlahnya cukup besar, maka peneliti menggunakan sampel. Menurut Suharsimi Arikunto, jika jumlah subjeknya besar maka dapat diambil 10-15\% atau lebih. Dengan memperhatikan pendapat diatas maka peneliti mengambil $20 \%$ dari jumlah populasinya, yakni 358 siswa menjadi 72 orang siswa yang diteliti.

Menurut Suharsimi Arikunto, instrumen pengumpulan data adalah alat bantu yang dipilih dan digunakan oleh peneliti dalam kegiatannya mengumpulkan data agar kegiatan tersebut menjadi bisa dipermudah olehnya. Alat bantu yang digunakan dalam pengumpulan data ini berupa alat ukur, kuesioner, soal tes atau soal dan lain sebagainya. ${ }^{13}$ Karena instrumen penelitian akan digunakan untuk melakukan pengukuran dengan tujuan menghasilkan data kuantitatif yang akan akurat, maka setiap instrumen harus mempunyai skala. Skala pengukuran merupakan kesepakatan yang digunakan sebagai acuan untuk

\footnotetext{
${ }^{11}$ Ahmad Tanzeh, Pengantar Metode Penelitian (Yogyakarta: Teras, 2009), 85.

12 Ibid.,120.

${ }^{13}$ Suharsimi Arikunto, Prosedur Penelitian Suatu Pedekatan Praktek (Jakarta: Rineka Cipta, 2010), 265.
} 
menentukan panjang pendeknya interval yang ada dalam alat ukur, sehingga alat ukur tersebut bila digunakan dalam pengukuran akan menghasilkan data kuantitatif. ${ }^{14}$ Lebih tepatnya, instrumen yang digunakan dalam penelitian ini yakni skala.

Uji validitas dan reliabilitas dalam uji coba instrumen penelitian ini dilaksanakan di SMP Dharma Wanita Pare yang berlokasi di Jl. Jend. Ahmad Yani No. 1 Pare Kediri. Uji coba instrumen ini dilaksanakan dengan tujuan untuk mengetahui apakah item soal yang akan diujikan di lapangan layak diujikan atau tidak. Dalam pengujian instrumen ini peneliti mengambil sampel sebanyak 20 dengan jumlah item soal variabel X 50 item dan variabel Y 50 item soal.

Reliabilitas menunjukkan pada suatu pengertian bahwa suatu instrumen cukup dapat dipercaya untuk digunakan sebagai alat mengumpulkan data, karena instrumen itu sudah baik ${ }^{15}$. Reliabilitas selain berarti ketelitian dalam melakukan pengukuran juga dapat diartikan sebagai ketelitian alat ukur yang digunakan dengan demikian, uji reliabilitas yang akan dibahas pada bagian ini adalah menguji ketelitian kuesioner yang akan digunakan dalam tehnik pengumpulan data. ${ }^{16}$

Mencari reliabilitas rumusnya sama dengan product moment yang kemudian dimasukkan rumus Spearman-Brown. ${ }^{17}$

$$
\begin{aligned}
& r 11=\frac{2 r^{1 / 2} 1 / 2}{\left(1+r^{1 / 2} 1 / 2\right)} \\
& \text { Keterangan, } \\
& \text { r } 1 / 21 / 2=\text { korelasi antara skor-skor setiap belahan tes. } \\
& \text { r11 = relibilitas instrumen. }
\end{aligned}
$$

\footnotetext{
${ }^{14}$ Sugiyono, Metode Penelitian Kuantitatif Kualitatif dan R \& D (Bandung, Alfabeta, 2015), 92.

${ }^{15}$ Sugiyono, Metode, 172.

${ }^{16}$ Abdurrahmat Fathoni, Metode Penelitian \& Teknik Penelitian Penyusunan Skripsi (Jakarta: Rineka Cipta, 2006), 125.

17 Suharsimi Arikunto, Prosedur Penelitian Suatu Pendekatan Praktik, Edisi Revisi, 223.
} 
Hasil analisis dari rumusan tersebut kemudian dikonsultasikan dengan product moment. Bila $r$ hitung lebih kecil dari $r$ table maka instrument itu tidak reliable, tetapi sebaliknya apabila $r$ hitung lebih besar dari $r$ table maka instrument itu realible artinya dapat dijadiakan alat pengumpul data. Peneliti menggunakan bantuan SPSS 16.0 for WIndows untuk menentukan reabilitas butir soal. Butir soal dikatakan reliabel jika $r_{\text {hitung }}>r_{\text {tabel }}$.

\section{Penyajian Data}

Penelitian tentang pengaruh kontrol diri terhadap tingkat religiusitas siswa kelas VIII di SMP Negeri 4 Pare Kediri. Data skala yang diambil menggunakan sampel dari populasi siswa di sekolah tersebut. Sampel yang diambil sebanyak 72 siswa. Data yang diambil berupa skor dari skala kontrol diri dan skala tingkat religusitas. Setiap butir soal yang diajukan telah di uji validitas dan uji reliabilitas dengan menggunakan program SPSS 16.0 for Windows.

Data skala diperoleh dengan cara mengujikan instrumen yang berbentuk skala likert kepada siswa di SMP Negeri 4 Pare yang telah ditentukan dalam penentuan sampel yakni sejumlah 72 siswa. Instrumen yang diujikan tersebut telah memenuhi uji validitas dan uji reliabilitas. Penulis menggunakan skala dengan jumlah pernyataan 30 butir soal untuk skala kontrol diri dan 40 butir soal untuk skala tingkat religiusitas. Prosentase jawaban skala kontrol diri yang dialami siswa kelas VIII di SMP Negeri 4 Pare yang diolah menggunakan program SPSS 16.0 for Windows. Tabel skor kontrol diri dan tabel frekuensi dapat dilihat pada lampiran 5. 
Berdasarkan tabel prosentase pada lampiran 5 dapat disimpulkan sebagai berikut :

Tabel 4.1

Rangkuman Prosentase Kontrol Diri

\begin{tabular}{|c|c|c|}
\hline NO & KATEGORI & PROSENTASE \\
\hline 1 & Sangat baik & $24 \%$ \\
\hline 2 & Baik & $18 \%$ \\
\hline 3 & Cukup baik & $19 \%$ \\
\hline 4 & Kurang baik & $21 \%$ \\
\hline 5 & Sangat kurang baik & $18 \%$ \\
\hline
\end{tabular}

Prosentase jawaban skala tingkat religiusitas yang dialami siswa kelas VIII di SMP Negeri 4 Pare yang diolah menggunakan program SPSS 16.0 for Windows. Tabel skor tingkat religiusitas dan tabel frekuensi dapat dilihat pada lampiran 6 . Berdasarkan tabel skor dan tabel prosentase tingkat religiusitas maka dapat ditarik kesimpulan sebagai berikut:

Tabel 4.2

Rangkuman Prosentase Tingkat Religiusitas

\begin{tabular}{|c|c|c|}
\hline NO & KATEGORI & PROSENTASE \\
\hline 1 & Sangat tinggi & $25 \%$ \\
\hline 2 & Tinggi & $15 \%$ \\
\hline 3 & Sedang & $21 \%$ \\
\hline 4 & Rendah & $22 \%$ \\
\hline 5 & Sangat rendah & $17 \%$ \\
\hline
\end{tabular}

\section{Analisis Data}

Analisis data dalam penelitian ini menggunakan uji validitas dan uji reliabilitas.

1. Uji Validitas 
Uji validitas yang digunakan pada penelitian ini untuk mengetahui kevalidan skala dalam pengumpulan data. Uji validitas data per-item soal dalam penelitian ini menggunakan program SPSS 16. For Windows. Item soal skala dalam uji validitas dikatakan valid jika $r_{\text {hitung }}>r_{\text {tabel }}$ pada nilai signifikan $5 \%$ atau 0,05 . Item soal skala dinyatakan tidak valid dalam uji validitas jika $\mathrm{r}_{\text {hitung }}<\mathrm{r}_{\text {tabel. }}$ Ringkasan hasil uji validitas akan disajikan di lampiran.

a. Uji Validitas Skala Variabel Kontrol Diri

Berdasar tabel uji skala validitas variabel pelaksanaan kontrol diri (lihat lampiran 7) dengan menggunakan sampel 72 siswa dan soal 30 item, yang dinyatakan valid ada 20 soal dan 10 soal dinyatakan tidak valid. Soal yang dinyatakan valid adalah soal nomor, 1, 2, 4, 6, 7, 9, 12, 13, $14,15,16,17,18,21,22,23,25,28,29,30$. Sedangkan soal yang dinyatakan tidak valid adalah soal nomer 3, 5, 8, 10, 11, 19, 20, 24, 26, 27.

b. Uji Validitas Skala Variabel Tingkat Religiusitas

Berdasar tabel uji skala validitas variabel tingkat religiusitas siswa (lihat lampiran 7) dengan menggunakan sampel 72 siswa dan soal 40 item, yang dinyatakan valid ada 36 soal dan 4 soal dinyatakan tidak valid. Soal yang dinyatakan valid adalah soal nomor $2,3,4,5,6,7,9,10,11,12,13,14$, $15,16,17,18,20,21,22,23,24,25,26,27,28,29,30,31,32,33,34,35,36,37$, 39,40 . Sedangkan yang tidak valid adalah soal nomer 1, 8, 19, 38 .

2. Uji Reliabilitas

a. Uji Reliabilitas Skala Kontrol Diri

Pengujian skala kontrol diri pada program SPSS 16.0 Windows. Dan menunjukkan hasil sebagai berikut:

Tabel 4.3

\section{Hasil Uji Reliabilitas Kontrol Diri}

Reliability Statistics

\begin{tabular}{|r|r|}
\hline $\begin{array}{c}\text { Cronbach's } \\
\text { Alpha }\end{array}$ & N of Items \\
\hline .677 & 31 \\
\hline
\end{tabular}


Berdasarkan tabel 4.3 diperoleh nilai koefisien Cronbach's Alpha (r hitung) sebesar 0,677 dimana nilai $\mathrm{r}$ tabel dengan $\alpha=0,05$ dan $d f=70$ adalah 0,2319. Karena $r_{\text {hitumg }}=0,677$ dan $r_{\text {tabel }}=0,2319$ maka $r$ hitung $>r$ tabel, sehingga dapat dikatakan bahwa instrumen skala kontrol diri tersebut dinyatakan reliabel.

b. Uji Reliabilitas Skala Tingkat Religiusitas

Tabel 4.4

\section{Hasil Uji Reliabilitas Skala Tingkat Religiusitas}



Berdasarkan tabel 4.4 diperoleh nilai koefisien Cronbach's Alpha ( $\mathrm{r}$ hitung) sebesar 0,721 dimana nilai $\mathrm{r}$ tabel dengan $\alpha=0,05$ dan $d f=70$ adalah 0,2319. Karena $r_{\text {hitung }}=0.721$ dan $r_{\text {tabel }}=0,2319$ maka $r_{\text {hitung }}>r_{\text {tabel, }}$ sehingga dapat dikatakan bahwa instrumen skala tingkat religiusitas tersebut dinyatakan reliabel. Berdasar tabel 4.3 dan tabel 4.4 yang menyatakan kedua skala tersebut dinyatakan reliabel sehingga keduanya dapat digunakan sebagai instrumen dalam penelitian ini.

\section{Pengujian Hipotesis}

Pengujian hipotesis pada penelitian ini dilakukan setelah dilakukan uji linieritas, tujuannya untuk mengetahui ada atau tidaknya kelinieran/ hubungan erat kedua variabel yang diteliti. Hasil pengujian kelinieran dari kedua variabel dapat dilihat dari tabel berikut: 
Tabel 5.3

\section{Hasil Uji Linieritas}

ANOVA Table

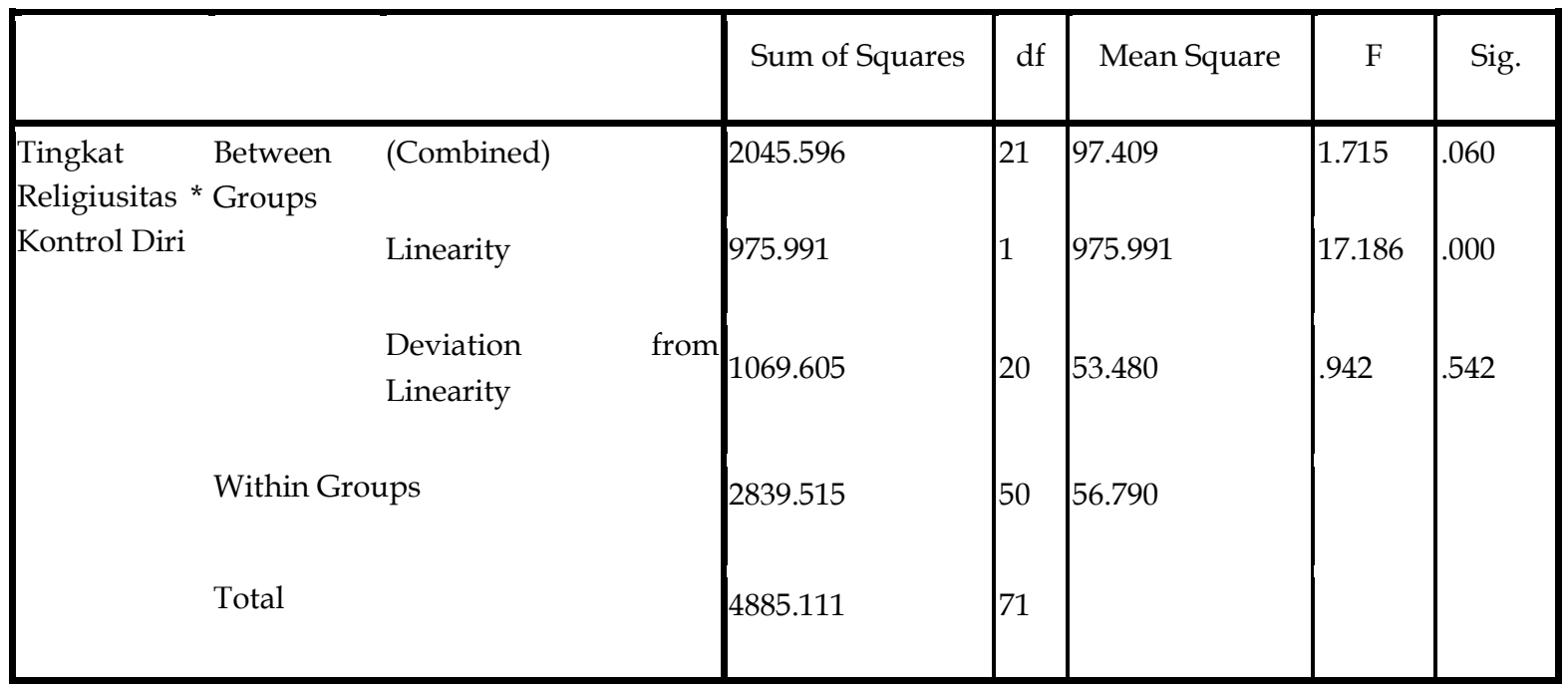

Sumber: Output SPSS 16.0

Pengambilan keputusan berdasarkan tabel 5.3 yakni dengan ketentuan jika signifikan $<0,05$ maka terdapat hubungan linear, sedangkan jika signifikan>0,05 maka tidak terdapat hubungan linear. Akan tetapi dari data di atas menunjukkan bahwa nilai signifikan $0,000<0,05$ sehingga dapat disimpulkan bahwa antara variabel kontrol diri dan variabel tingkat religiusitas terdapat hubungan linier.

Kedua variabel dinyatakan linear, maka dapat dilanjutkan untuk melakukan uji hipotesis dengan menggunakan regresi linear dengan SPSS 16.0 for windows sebagai berikut: 
Tabel 5.4

\section{Hasil Uji Regresi Linier}

Variables Entered/Removed ${ }^{b}$

\begin{tabular}{|l|l|l|l|}
\hline Model & $\begin{array}{c}\text { Variables } \\
\text { Entered }\end{array}$ & $\begin{array}{c}\text { Variables } \\
\text { Removed }\end{array}$ & Method \\
\hline 1 & Kontrol Diria &. & Enter \\
\hline
\end{tabular}

a. All requested variables entered.

b. Dependent Variable: Tingkat Religiusitas

ANOVA $^{b}$

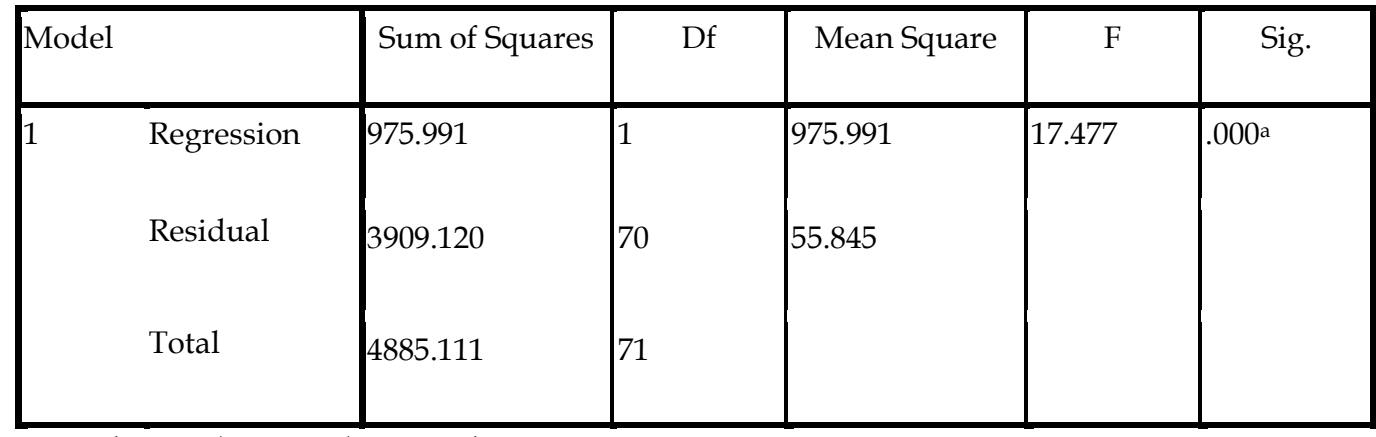

a. Predictors: (Constant), Kontrol Diri

b. Dependent Variable: Tingkat Religiusitas

Coefficients ${ }^{a}$

\begin{tabular}{|c|c|c|c|c|c|}
\hline \multirow[b]{2}{*}{ Model } & \multicolumn{2}{|c|}{ Unstandardized Coefficients } & \multirow{2}{*}{$\begin{array}{c}\begin{array}{c}\text { Standardized } \\
\text { Coefficients }\end{array} \\
\text { Beta }\end{array}$} & \multirow[b]{2}{*}{$\mathrm{T}$} & \multirow[b]{2}{*}{ Sig. } \\
\hline & B & Std. Error & & & \\
\hline (Constant) & 80.505 & 14.113 & & 5.704 & .000 \\
\hline Kontrol Diri & .626 & .150 & .447 & 4.181 & .000 \\
\hline
\end{tabular}

a. Dependent Variable: Tingkat Religiusitas 
Berikut ini persamaan regresi dari hasil pengujian dengan rumus sebagai berikut:

$$
\begin{aligned}
& Y=a+b X \\
& Y=80.505+0.626 X
\end{aligned}
$$

Dimana :

$$
\begin{aligned}
& Y=\text { Tingkat Religiusitas } \\
& X=\text { Kontrol Diri } \\
& a=\text { Konstanta } \\
& b=\text { Koefisien Regresi }
\end{aligned}
$$

Tabel 5.4 menunjukkan bahwa konstanta (a) 80,505 ,secara statistik diterjemahkan dengan menganggap $x=0$, koefisien regresi (b) sebesar 0,626 maka $Y=80,505$. Nilai koefisien regresi ini menunjukkan bahwa setiap terjadi kenaikan satu satuan pada pelaksanaan kontrol diri maka akan diikuti kenaikan tingkat religiusitas siswa sebesar 80,505 satuan.

Besarnya pengaruh kontrol diri terhadap tingkat religiusitas siswa kelas VIII di SMP Negeri 4 Pare Kediri dapat dilihat dari koefisien determinasi (R-Square). Kesimpulannya bahwa kontrol diri pada siswa kelas VIII di SMP Negeri 4 Pare Kediri memiliki pengaruh terhadap tingkat religiusitasnya, sebagaimana dilihat pada tabel berikut:

\section{Tabel 5.5}

\section{Koefisien Determinasi}

Model Summary

\begin{tabular}{|l|l|l|l|l|}
\hline Model & \multicolumn{1}{|c|}{$\mathrm{R}$} & R Square & $\begin{array}{c}\text { Adjusted R } \\
\text { Square }\end{array}$ & $\begin{array}{c}\text { Std. Error of the } \\
\text { Estimate }\end{array}$ \\
\hline 1 & $.447^{\mathrm{a}}$ & .200 & .188 & 7.473 \\
\hline
\end{tabular}

a. Predictors: (Constant), Kontrol Diri

Sumber: Output SPSS 16.0 
Berdasarkan tabel 5.5 dapat diketahui bahwa nilai R- square adalah 0,200. Nilai ini mengandung arti bahwa pengaruh Kontrol Diri $(X)$ terhadap Tingkat Religiusitas (Y) adalah sebesar $20 \%$ sedangkan $80 \%$ Tingkat Religiusitas dipengaruhi oleh faktor lain yang tidak diteliti.

\section{Kesimpulan.}

Berdasarkan hasil persentase dari kontrol diri yang menunjukkan bahwa kontrol diri yang dialami oleh siswa di sekolah tersebut $24 \%$ dalam kategori sangat baik, 18\% siswa memiliki kategori baik, 19\% siswa memiliki kategori cukup baik, $21 \%$ memiliki kategori kurang baik dan 18\% memiliki kategori sangat kurang baik. Hal ini menujukkan bahwa kontrol diri siswa kelas VIII di SMP Negeri 4 Pare Kediri rata-rata memiliki kategori baik.

Berdasarkan hasil persentase tingkat religiusitas siswa menunjukkan bahwa $25 \%$ siswa memiliki kategori tingkat religiusitas yang sangat tinggi, $15 \%$ siswa memiliki kategori tingkat religiusitas yang tinggi, 21\% siswa memiliki kategori tingkat religiusitas yang sedang, 22\% siswa memiliki kategori tingkat religiusitas yang rendah dan 17\% siswa memiliki kategori tingkat religiusitas yang sangat rendah. Hal ini menujukkan bahwa tingkat religiusitas siswa kelas VIII di SMP Negeri 4 Pare Kediri rata-rata memiliki kategori tinggi.

Berdasarkan hasil penelitian tentang pengaruh kontrol diri terhadap tingkat religiusitas menunjukkan nilai signifikan sebesar 0,000. Pengambilan keputusan dengan ketentuan jika nilai sig $<0,05$ yang berarti ada hubungan antara kedua variabel tersebut. Hasil uji linieritas menunjukkan sig $0,000<0,05$ sehingga antara variabel kontrol diri dengan variabel tingkat religiusitas terdapat pengaruh (linear). Jadi dapat disimpulkan bahwa pengaruh variabel $\mathrm{X}$ terhadap $\mathrm{Y}$ lemah yakni memiliki pengaruh sebesar 0,200 atau 20\% sedangkan $80 \%$ dipengaruhi oleh faktor lain yang tidak diteliti. 
Julianne Kamelia Riza

Pengaruh Kontrol Diri...

\section{Daftar Pustaka}

Andriani, D Nadifa. "Kajian Teori Kontrol Diri” (Jurnal UIN Malang, 2014), (online) http://etheses.uin-malang.ac.id, diakses pada tanggal 08 agustus 2017.

Arikunto, Suharsimi. Prosedur Penelitian Suatu Pedekatan Praktek. Jakarta: Rineka Cipta, 2010.

Fathoni, Abdurrahmat. Metode Penelitian \& Teknik Penelitian Penyusunan Skripsi. Jakarta: Rineka Cipta, 2006.

Ghufron, M. Nur \& Rini Risnawati S, Teori-Teori Psikologi. Jogjakarta: Ar-Ruzz Media, 2014.

Said, Alwi. Perkembangan Religiusitas Remaja. Yogyakarta: Kaukaba Dipantara, 2014.

Sugiyono, Metode Penelitian Kuantitatif Kualitatif dan $R \mathcal{E} D$. Bandung, Alfabeta, 2015.

Tanzeh, Ahmad Pengantar Metode Penelitian. Yogyakarta: Teras, 2009. 